\title{
Influence of the feeding regime on the start-up and operation of the autotrophic nitrogen removal process
}

\author{
Stijn WH van Hulle ${ }^{1,2 *}$, Helge Vandeweyer ${ }^{1}$, Wim Audenaert ${ }^{1,2}$, \\ Annick Monballiu ${ }^{3}$ and Boudewijn Meesschaert ${ }^{3}$ \\ ${ }^{1}$ EnBiChem Research Group, University College West Flanders, Ghent University Association, \\ Graaf Karel de Goedelaan 5, 8500 Kortrijk, Belgium \\ ${ }^{2}$ BIOMATH, Department of Applied Mathematics, Biometrics and Process Control, Ghent University, \\ Coupure Links 653, B-9000 Ghent, Belgium \\ ${ }^{3}$ Chemistry Department, Catholic University College of Bruges-Ostend, Leuven University Association, \\ Zeedijk 101, B-8400 Ostend, Belgium
}

\begin{abstract}
The autotrophic nitrogen removal process (partial nitritation combined with the Anammox process) is a sustainable nitrogen removal technique for nitrogen-rich streams. A modelling and experimental study was performed to define optimal process conditions for the autotrophic nitrogen removal process. Special attention was given to the influence of feeding characteristics on the performance of both the partial nitritation reactor and the Anammox reactor. It was revealed that the feeding regime is an important factor in the successful start-up of the Anammox process. Nitrite concentration peaks at the beginning of a feeding period will lead to an unsuccessful start-up, while a slow input of nitrogen speeds up the process. Feeding regimes are less important in partial nitritation reactors since laboratory results show that slow or fast supply of influent does not influence the growth of ammonium oxidisers.
\end{abstract}

Keywords: Anammox, autotrophic nitrogen removal, modelling, optimisation, start-up analysis

\section{Introduction}

Nitrogen, which is generally in the form of ammonium or organic nitrogen, is removed by biological nitrificationdenitrification in most modern wastewater treatment plants (WWTP). Benefits of the process are the high potential removal efficiency, high process stability and reliability, relatively easy process control, low area requirement and moderate cost (Tchobananoglous, 2003). As a first step, ammonium is converted to nitrate (nitrification). In a second step, nitrate is converted to nitrogen gas (denitrification).

A major stress factor on nitrogen removal is reject-water from sludge digesters, which is recycled back to the main WWTP. This reject-water can represent up to $25 \%$ of the total nitrogen load, but only 1 to $2 \%$ of the volumetric load (Janus and Van der Roest, 1997). Treating this return stream separately by nitrification-denitrification would become expensive and non-sustainable, as this treatment would require large oxygen consumption and the addition of a carbon source due to the high nitrogen concentration (up to $2 \mathrm{~g} \cdot \ell^{-1} \mathrm{~N}$ ) and unfavourable carbon-to-nitrogen $\left(\mathrm{C} \mathrm{N}^{-1}\right)$ ratio for denitrification (Henze et al., 2008). This would therefore result in high operational costs. Also, other streams have a high nitrogen and a low organic carbon content, such as anaerobic digester effluents, landfill leachate and industrial wastewaters (Wiesmann, 1994). Treating these streams with conventional nitrification-denitrification will lead to high operational costs and possibly also the emission of large amounts of greenhouse

\footnotetext{
* To whom all correspondence should be addressed.

正 +32 (56) 241237; fax: +32 (56) 241224; e-mail: Stijn.Van.Hulle@,Howest.be

Received 19 November 2010; accepted in revised form 21 April 2011.
}

gasses (Jetten et al., 1997; Kampschreur et al., 2009).

A more sustainable and cost-effective alternative to conventional nitrogen removal systems is the autotrophic conversion of ammonium to nitrogen gas, especially in cases where the carbon-to-nitrogen ratio is low and aeration capacity is limiting (Van Dongen et al., 2001). The first step, called 'partial nitritation', includes a conversion of the incoming ammonium to nitrite, obtaining a ammonium:nitrite ratio of 1:1 (Hellinga et al., 1998). This partial nitritation process can only be realised when the nitrite-oxidizing bacteria are inhibited, outcompeted or removed, while the ammonium oxidizers are retained due to a higher relative growth rate of ammonium oxidizers at higher temperature $\left(>25^{\circ} \mathrm{C}\right)$, oxygen limitation (0.3-0.5 $\mathrm{mg} \cdot \ell^{-1} \mathrm{O}_{2}$ ) and higher $\mathrm{pH}$ (Van Hulle et al., 2010). The second process is the anaerobic oxidation of ammonium (Anammox) with nitrite as electron acceptor (Van De Graaf et al., 1996; Jetten et al., 1997). With this Anammox process, ammonium and nitrite are combined under anoxic conditions, without addition of an external carbon source, directly to nitrogen gas, with the production of a small amount of nitrate (Jetten et al., 1999).

To date, several pilot-scale and full-scale reactors are in operation (Van Hulle et al., 2010). However, a shortcoming in the application of the Anammox process is the slow growth rate, resulting in a very time-consuming experimental startup (Hao et al., 2002; Strous et al., 1998; Van der Star et al., 2007).

In view of the very long start-up time, a model-based analysis was performed to define optimal process conditions (temperature, oxygen supply, $\mathrm{pH}$ and biomass retention) for both an oxygen-limited partial nitritation reactor and an Anammox reactor. The simulation results were discussed in detail in a previous publication (Veys et al., 2010), and a summary is provided in Table 1. 


\begin{tabular}{|c|c|c|}
\hline \multicolumn{3}{|c|}{$\begin{array}{c}\text { Table } 1 \\
\text { Optimal conditions for the autotrophic nitrogen } \\
\text { removal process as determined by a modelling } \\
\text { study (Veys et al., 2010) }\end{array}$} \\
\hline & Partial nitritation & Anammox \\
\hline Temperature $\left({ }^{\circ} \mathrm{C}\right)$ & $30-40$ & $30-40$ \\
\hline $\mathrm{pH}$ & $7-8$ & $7-8.5$ \\
\hline Minimal sludge age (d) & 25 & 40 \\
\hline $\mathrm{O}_{2}$ concentration $\left(\mathrm{mg} \cdot \ell^{-1} \mathrm{O}_{2}\right)$ & $0.04-0.06$ & 0 \\
\hline
\end{tabular}

One important factor not considered in the previous study is the feeding characteristics of the reactor. De Clippeleir et al. (2009) stated that a low substrate shock (a low volumetric exchange ratio) resulted in a faster start-up of an oxygenlimited autotrophic nitrogen removal sequencing batch reactor (SBR). Van Hulle et al. (2005) stated that a dedicated start-up for a partial nitrification reactor is necessary.

In this study, it is demonstrated that applying the conditions in Table 1 does not always lead to a successful start-up. The feeding regime plays an important role in the successful start-up of Anammox reactors. As such this paper focuses on this feeding regime and aims at exploring the related problems and/or bottlenecks in view of the establishment of a start-up protocol.

\section{Methods}

\section{Reactor systems}

\section{Partial nitritation reactor}

The partial nitritation reactor filled with $2 \ell$ of nitrifying and denitrifying sludge of the Harelbeke municipal WWTP (www.aquafin.be) was initially fed with $0.5 \ell$ of synthetic influent (prepared with tap water) containing $1 \mathrm{~g} \cdot \ell^{-1} \mathrm{NH}_{4} \mathrm{Cl}-\mathrm{N}$ and an equimolar amount of $\mathrm{NaHCO}_{3}$, reaching a working volume of $2.5 \ell$. Each day, $0.5 \ell$ of effluent was drawn out of the reactor after a biomass settling period of $30 \mathrm{~min}$, followed by a filling period with $0.5 \ell$ of influent. This results in a hydraulic residence time (HRT) of $5 \mathrm{~d}$ and a loading rate of $0.2 \mathrm{~g} \cdot \ell^{-1} \cdot \mathrm{d}^{-1} \mathrm{~N}$. After $44 \mathrm{~d}$ the loading rate was increased to $0.4 \mathrm{~g} \cdot \ell^{-1} \cdot \mathrm{d}^{-1} \mathrm{~N}$ by increasing the influent and effluent volume to $1 \ell$. As such, the HRT was decreased to $3 \mathrm{~d}$. The reactor conditions are the same as the optimal conditions found by the simulation study of Veys et al. (2010) (Table 1), with the exception of $\mathrm{O}_{2}$ concentration. The $\mathrm{O}_{2}$ concentration simulated by the model $\left(0.04-0.06 \mathrm{mg} \cdot \ell^{-1} \mathrm{O}_{2}\right)$ was lower than the applied set point in the laboratory reactor $\left(0.2-0.5 \mathrm{mg} \cdot \ell^{-1} \mathrm{O}_{2}\right)$, as the simulation model assumes perfect mixing. However, in practice, floc formation will induce an oxygen concentration gradient and, consequentially, a higher oxygen bulk concentration.

After 100 days of operation, $2 \ell$ of the sludge was transferred to a $20 \ell$ reactor. In this reactor, $8 \ell$ of nitrifying and denitrifying sludge of the Harelbeke municipal WWTP was also added. This reactor was fed on a daily basis with $10 \ell$ of synthetic influent containing $1 \mathrm{~g} \cdot \ell^{-1} \mathrm{NH}_{4} \mathrm{Cl} \mathrm{N}$. The same operational conditions as for the smaller reactor were applied, except that the HRT was decreased to $2 \mathrm{~d}$.

After $104 \mathrm{~d}$ of operation, a microfiltration membrane (pore size of $0.45 \mu \mathrm{m}$ ) was placed in the $20 \ell$ reactor, so that it was transformed to a membrane bioreactor (MBR). The reactor was fed continuously with a flow rate of $10 \ell \cdot$ day $^{-1}$, reaching a HRT of $2 \mathrm{~d}$. All other conditions were kept constant in the reactor.

\section{Anammox reactor}

Two Anammox reactors were operated on a different feeding regime to observe the effect on their operation, i.e., on the removal of ammonium and nitrite. The 'fast-fill' SBR reactor was operated with a feed period of $1 \mathrm{~min} \cdot \mathrm{d}^{-1}$, while the 'slowfill' reactor was fed continuously.

The fast-fill SBR reactor with a working volume of $3 \ell$ was inoculated with $1 \ell$ of nitrifying and denitrifying sludge, and $1 \ell$ of anaerobic digester sludge of the Harelbeke WWTP. On a daily basis, $1 \ell$ of synthetic influent containing $\left(\mathrm{NH}_{4}\right)_{2} \mathrm{SO}_{4}$, $\mathrm{NaNO}_{2}$ and other minor components (Table 2) was fed into the reactor. The reactor conditions were the same as the optimal conditions found by the simulation study of Veys et al. (2010) (Table 1). The biomass was able to settle for $30 \mathrm{~min}$ before 1 $\ell$ was withdrawn from the reactor. As such, a HRT of $3 \mathrm{~d}$ was reached. In order to achieve anoxic conditions, the reactor was flushed with $\mathrm{N}_{2}$ gas. After this flushing, $\mathrm{KHCO}_{3}$ was added to the reactor in an equimolar amount compared to ammonium. A continuously operating slow-fill reactor was inoculated with $600 \mathrm{~m} \ell$ of sludge of 2 different WWTP: the Harelbeke municipal WWTP and a landfill leachate WWTP. The top of the reactor was packed with polyurethane foam to ensure biomass retention. After start-up, it was estimated that about $10 \%$ of the biomass was present in this foam. The reactor was initially fed with a synthetic solution (prepared with tap water) containing $100 \mathrm{mg} \cdot \ell^{-1} \mathrm{~N}\left(\mathrm{NH}_{4}\right)_{2} \mathrm{SO}_{4}, 40 \mathrm{mg} \cdot \ell^{-1} \mathrm{~N} \mathrm{NaNO}_{2}, 0.5 \mathrm{~g} \cdot \ell^{-1} \mathrm{KHCO}_{3}$, and some other minor components (see Table 2), at a flow rate of $1.7 \mathrm{~m} \ell \cdot \mathrm{min}^{-1}$ to reach a HRT of $10 \mathrm{~h}$. No $\mathrm{N}_{2}$ flushing was applied in this reactor. During operation the influent concentration was gradually increased. The reactor conditions were the same as the optimal conditions found by the simulation study of Veys et al. (2010) (Table 1).

\begin{tabular}{|c|c|}
\hline \multicolumn{2}{|c|}{$\begin{array}{c}\text { Table } 2 \\
\text { Minor component composition of } \\
\text { the synthetic wastewater of the } \\
\text { Anammox reactors used in this } \\
\text { study according to Dapena-Mora et } \\
\text { al. (2004) (expressed in } g \cdot \ell^{-1} \text { ) }\end{array}$} \\
\hline Component & Concentration $\left(\mathrm{g} \cdot \ell^{-1}\right)$ \\
\hline $\mathrm{NaH}_{2} \mathrm{PO}_{4} \cdot 2 \mathrm{H}_{2} \mathrm{O}$ & 0.029 \\
\hline $\mathrm{CaCl}_{2}$ & 0.226 \\
\hline $\mathrm{MgSO}_{4} \cdot 7 \mathrm{H}_{2} \mathrm{O}$ & 0.2 \\
\hline $\mathrm{FeSO}_{4} \cdot 7 \mathrm{H}_{2} \mathrm{O}$ & 0.021 \\
\hline EDTA $2 \mathrm{H}_{2} \mathrm{O}$ & 0.0076 \\
\hline Trace elements & $1.25 \mathrm{~m} \ell \cdot \ell^{-1}$ \\
\hline
\end{tabular}

Effluent suspended solid concentration was not measured on a regular basis, but for both the fast-fill and the slow-fill reactor a clear effluent without turbidity was obtained. We therefore consider the loss of biomass in the effluent to be very low.

\section{Chemical analysis}

The concentration of ammonium-N, nitrite-N and nitrate$\mathrm{N}$ was measured colourimetrically according to Standard Methods (1998).

\section{Modeling and simulation of the Anammox reactor}

For the simulations, a previously-developed model (Wyffels et al., 2004; Dapena-Mora et al., 2004, Veys et al., 2010) was extended with Haldane kinetics to describe the dependence of 
the Anammox growth rate on nitrite:

$$
f\left(\mathrm{NO}_{2}^{-}\right)=\frac{\left[\mathrm{NO}_{2}^{-}\right]}{\frac{\left[\mathrm{NO}_{2}^{-}\right]^{2}}{\mathrm{~K}_{\mathrm{I}}}+\mathrm{K}_{\mathrm{NO}_{2}^{-}}+\left[\mathrm{NO}_{2}^{-}\right]}
$$

where:

$$
\begin{aligned}
& K_{\mathrm{NO} 2-}=0.3 \mathrm{mg} \cdot \ell^{-1} \mathrm{~N} \text { and } \\
& K_{I}=200 \mathrm{mg} \cdot \ell^{-1} \mathrm{~N}
\end{aligned}
$$

As such the expression for the growth rate of the Anammox organisms is presented in the equation below. Monod kinetics were used to describe the dependency of the growth rate of Anammox on ammonium. An additional inhibition term was used to describe an eventual inhibition of the Anammox organisms by oxygen.

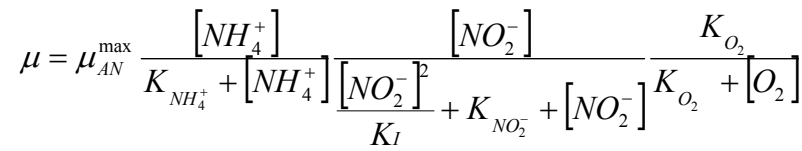

The ammonium and nitrite concentration values are expressed in $\mathrm{mg} \cdot \ell^{-1} \mathrm{~N}$, the oxygen concentration is expressed in $\mathrm{mg} \cdot \ell^{-1}$ $\mathrm{O}_{2}$ and the concentration of Anammox biomass is expressed in $\mathrm{mg} \cdot \ell^{-1} \mathrm{COD}$. The maximum specific growth rate of the Anammox biomass $\left(\mu_{\mathrm{AN}}\right)$ was derived from Strous et al. (1998) and was set to a value of $0.08 \mathrm{~d}^{-1}$ at $35^{\circ} \mathrm{C}$. The affinity constant for ammonium $\left(K_{\mathrm{NH}^{+}}\right)$was set to $0.3 \mathrm{mg} \cdot \ell^{-1} \mathrm{~N}$, while the inhibition constant for oxygen was set to $0.01 \mathrm{mg} \cdot \ell^{-1} \mathrm{O}_{2}$. The stoichiometry of the Anammox process was based on the reaction stoichiometry put forward by Strous et al. (1998), as implemented by Dapena-Mora et al. (2004):

$$
\begin{aligned}
& 1 \mathrm{NH}_{3}+1,32 \mathrm{NO}_{2}^{-}+0,066 \mathrm{H}^{+}+0,066 \mathrm{CO}_{2} \\
& \rightarrow 1,02 \mathrm{~N}_{2}+0,26 \mathrm{NO}_{3}^{-}+1,96 \mathrm{H}_{2} \mathrm{O}+0,066 \mathrm{CH}_{2} \mathrm{O}_{0,5} \mathrm{~N}_{0,15}
\end{aligned}
$$

The extended model as well as the SBR reactor configuration discussed below were implemented in the simulation program WEST ${ }^{\circledR}$ (Vanhooren et al., 2003).

\section{Results}

\section{Experimental results of the partial nitritation reactor}

Two weeks after start-up, a successful operation of the partial nitritation reactor was noticed, i.e., production of an ammonium:nitrite ratio of 1:1 (Fig. 1). Since in both reactors only small amounts of nitrate were observed in the effluent, nitrite-oxidizing bacteria are not present in high concentrations. Both the SBR and the MBR reactor can produce an Anammox suited effluent. As such, it can be seen that both a discontinuous and a continuous feeding regime give excellent results in view of coupling with an Anammox reactor. Hence, feeding regime is not important for the partial nitritation reactor and start-up can be accomplished by slow or fast feeding. Some researchers even state that a discontinuous operation is beneficial, as it imposes more stress on the nitrite-oxidising organisms. Hyungseok et al. (1999), for example, reported that nitrate formation can effectively be prevented by frequent switching between oxic and anoxic phases. Therefore, the aeration is switched off before all the ammonium is consumed and before nitrite can be further converted to nitrate. A continuation of the aeration phases in a SBR lowered the stress on nitrite oxidisers, resulting in an increase of nitrate (Katsogiannis et al., 2003; Blackburne et al., 2008).
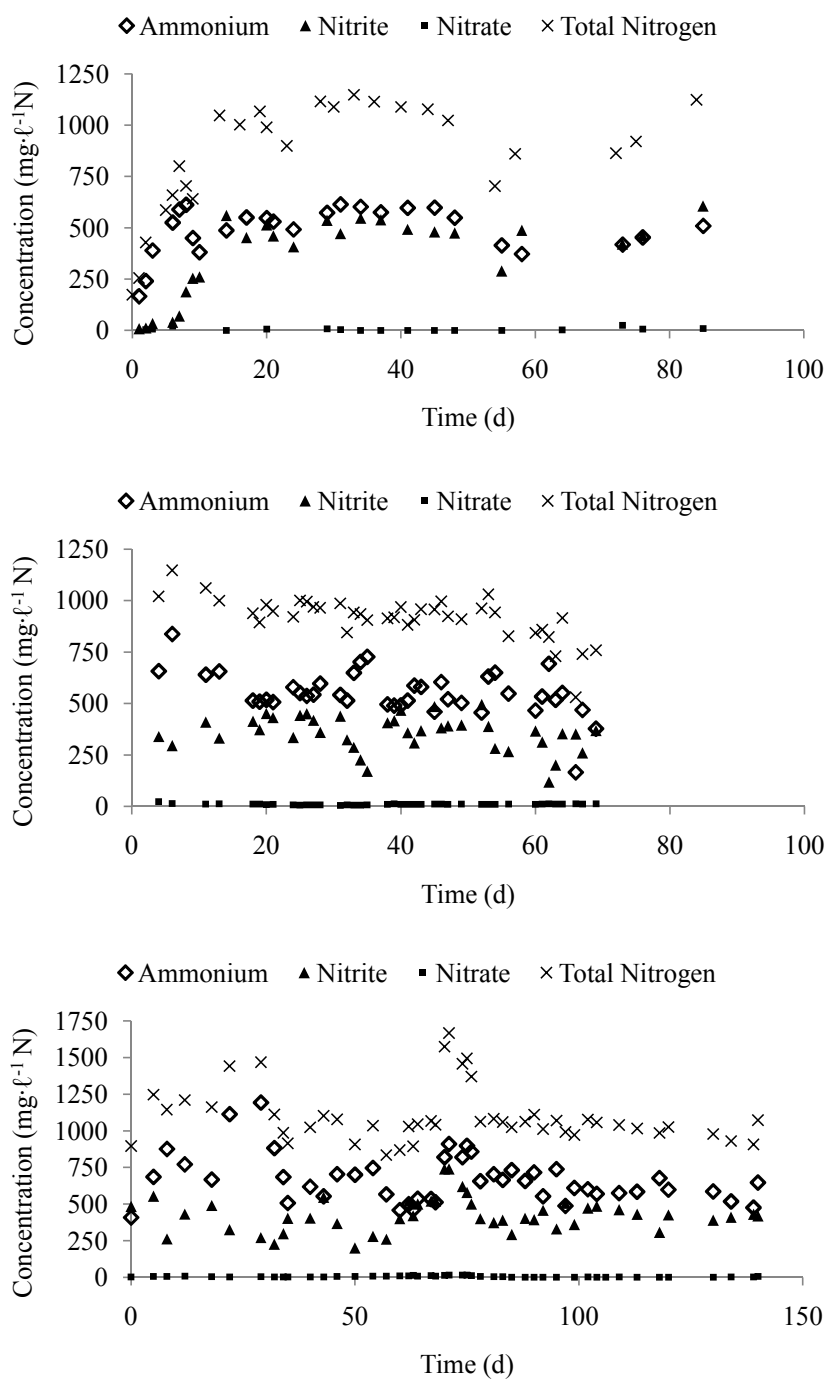

Figure 1

Overview of the $N$ concentration in the effluent of a fast-fill partial nitritation reactor with a volume of $3 \ell$ (top), a fast-fill partial nitritation reactor with a volume of $20 \ell$ (middle) and a slow-fill partial nitritation reactor with a volume of $20 \ell$ (bottom)

\section{Simulation results of the Anammox reactor}

Based on the optimal conditions for the Anammox process (Table 1), the effect of feeding characteristics on the performance of the Anammox reactor was tested by simulating the nitrogen gas production under different conditions. A first simulation run was performed with an Anammox SBR that was operated according to the start-up strategy of DapenaMora et al. (2004). A 6-h cycle and a volume exchange ratio of $25 \%$ were applied. Within the 6 -h cycle, $5.5 \mathrm{~h}$ (330 min) were used for filling and reaction, 20 min were used for settling and the biomass was withdrawn for $10 \mathrm{~min}$. A second simulation was run with a 1-min feed period and a period of $329 \mathrm{~min}$ of reaction without feeding. Again, $20 \mathrm{~min}$ were used for settling and the biomass was withdrawn for $10 \mathrm{~min}$. Figure 2 (top) gives an overview of the nitrogen concentration in the influent used to simulate the performance of these 2 Anammox SBR reactors.

In Fig. 2 (bottom) the performance in terms of nitrogen gas production is demonstrated. The nitrogen gas production 

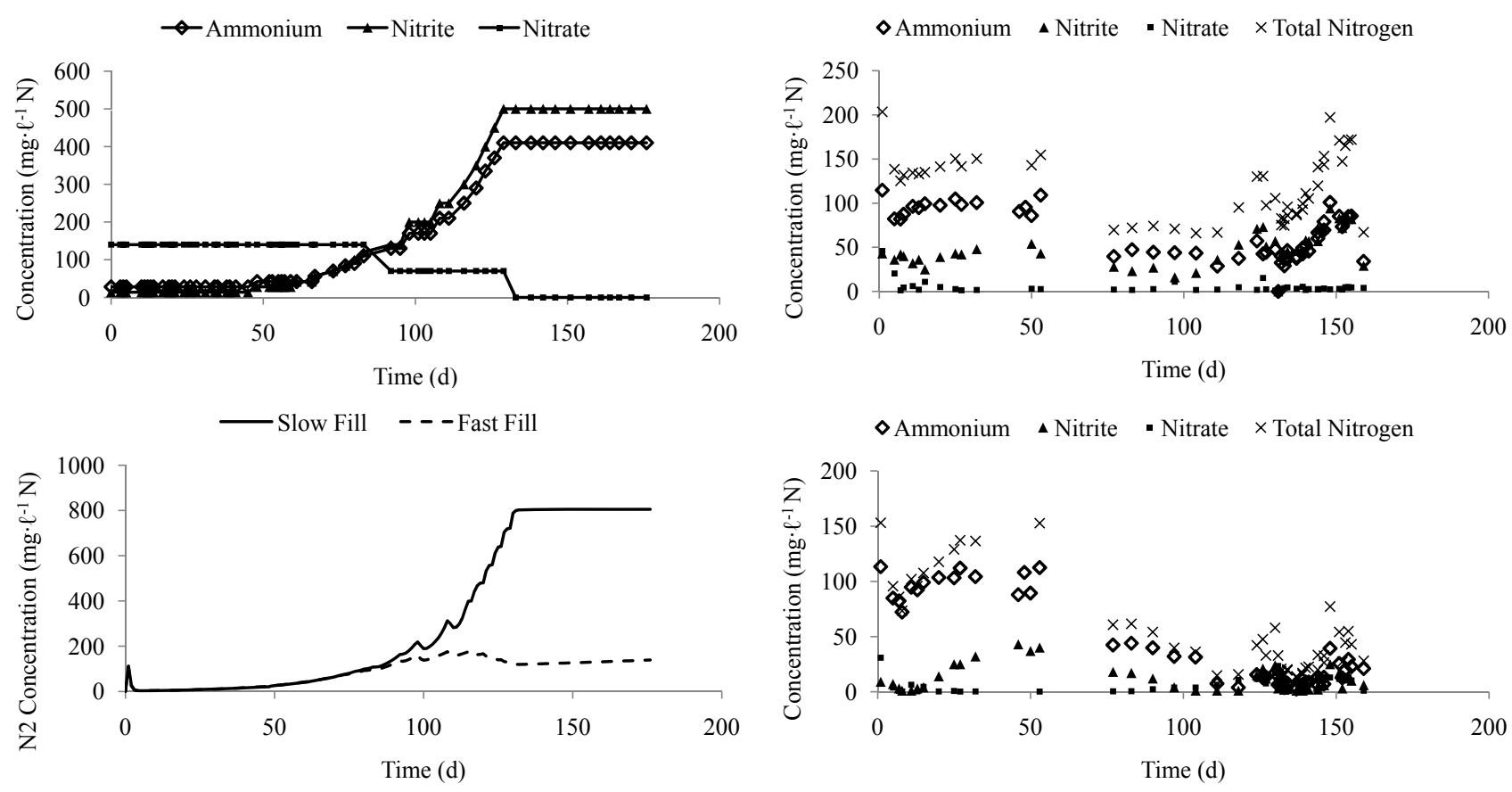

Figure 2

The influent nitrogen concentration for simulation of the Anammox SBR reactor (top) and the simulated nitrogen gas production of a slow-fill and a fast-fill Anammox reactor (bottom)

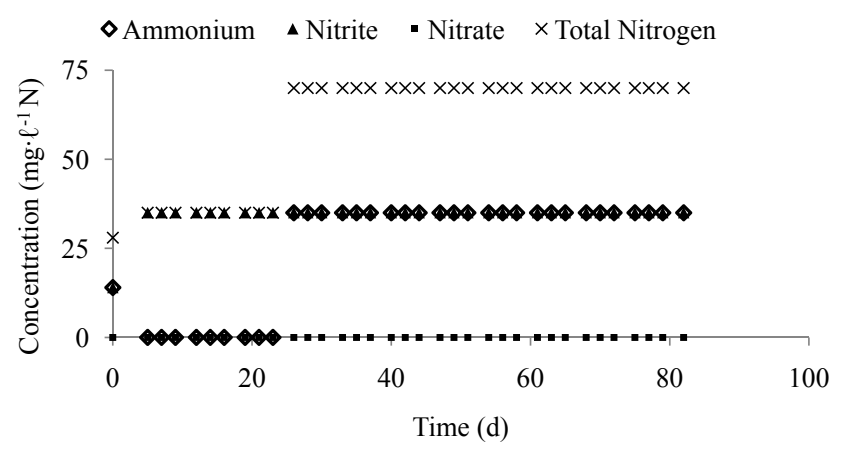

\section{Experimental results for the Anammox reactor}

When operating the fast-fill Anammox reactors, initially bacterial decay occurs causing high ammonium concentration and organic carbon in the effluent. The ammonium concentration was therefore reduced in the influent until the ammonium concentration decreased to lower values, while the nitrite concentration was maintained at $35 \mathrm{mg} \cdot \ell^{-1} \mathrm{~N}$. After $25 \mathrm{~d}$, the ammonium concentration in the influent was also increased to $35 \mathrm{mg} \cdot \ell^{-1} \mathrm{~N}$. Figure 3 shows that the ammonium concentration in the influent and effluent are the same, while the nitrite concentration in the effluent is lower than in the influent. It can be concluded that denitrifying bacteria used the organic carbon derived from bacterial decay to convert the incoming nitrite to nitrogen gas by denitrification. Since ammonium was not removed, it can be stated that Anammox bacteria are not active in this laboratory reactor. A possible explanation could be the feeding characteristics of this reactor. These tests were performed several times and every time similar results were obtained.

In the slow-fill reactor, initial bacterial decay also occurs, leading to high concentrations of organic carbon. This organic carbon will also be used to denitrify the incoming nitrite, while the ammonium concentration stays equal to that of the influent. The bacterial community stabilises after $30 \mathrm{~d}$ and, since no organic carbon is added to the influent, less denitrification will occur and so less nitrite will be removed. After $60 \mathrm{~d}$ of operation, nitrogen removal was very small. Fux (2003) showed in a long-term experiment that maintaining a nitrite concentration of $40 \mathrm{mg} \cdot \ell^{-1} \mathrm{~N}$ over several days led to the irreversible inactivation of the Anammox organisms. To ensure that no inhibition can occur, the influent nitrogen concentration was reduced (20 $\mathrm{mg} \cdot \ell^{-1} \mathrm{NO}_{2}-\mathrm{N}$ and $\left.50 \mathrm{mg} \cdot \ell^{-1} \mathrm{NH}_{4}-\mathrm{N}\right)$. After $30 \mathrm{~d}$ of operation the removal of ammonia and nitrite was observed to be increasing (Figs. 4 and 5). This gives a first indication of Anammox activity. This nitrogen removal was accompanied with production of a small amount of nitrate, which can also be attributed 


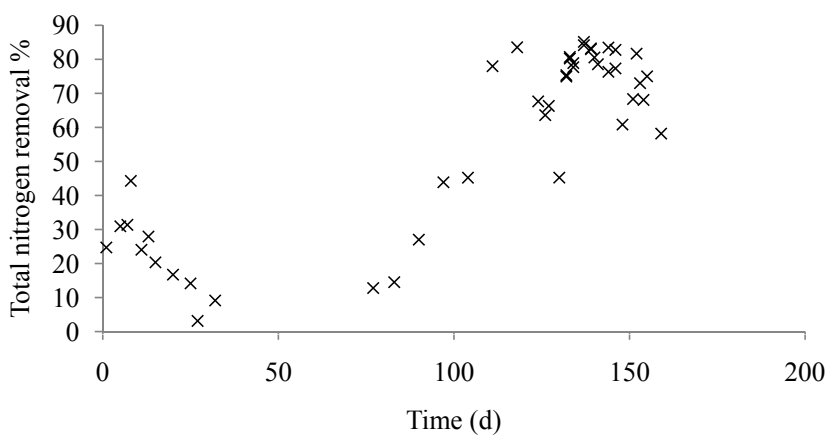

Figure 5

Nitrogen removal in the continuous slow-fed Anammox reactor

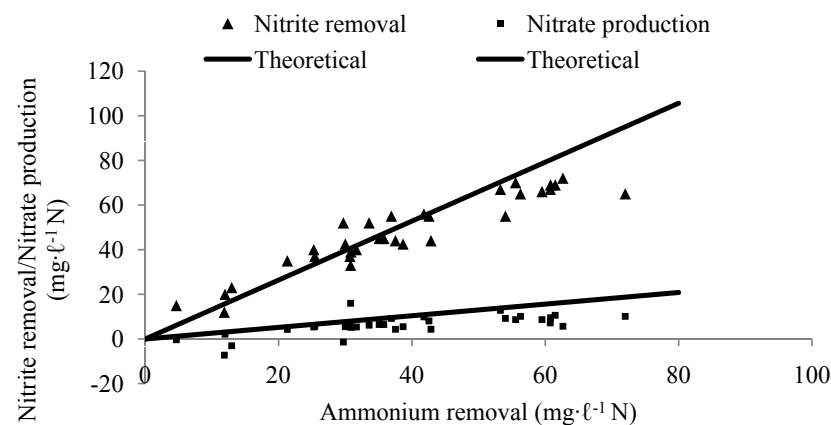

Figure 6

Removal of nitrite and production of nitrate as function of ammonium removal: experimental and theoretical values.

to the Anammox process, as $26 \%$ of the removed ammonium is converted to nitrate (Strous et al., 1998).

After about $100 \mathrm{~d}$ of operation, an exponential increase in nitrogen removal was detected. Because of this increasing removal the influent ammonium and nitrite concentration values were increased. After about $130 \mathrm{~d}$ of operation the sludge colour changed to red, which is the typical colour of Anammox biomass (Van de Graaf et al., 1996).

In order to prove the existence of Anammox organisms in the reactor some stoichiometric and kinetic parameters have been calculated from the experimental data and compared with typical Anammox values that are reported in the literature. First, the obtained doubling time was calculated based on the exponential increase of the nitrogen removal and the increase in influent total nitrogen concentration. This resulted in a doubling time of, respectively, $10 \mathrm{~d}$ and $19 \mathrm{~d}$, which is very similar to reported values in literature (Stous et al., 1998). The somewhat higher value obtained when using influent total nitrogen concentration can be explained by the fact that the influent concentration was not continuously increased, because of operational problems such as pump failure. Other typical values that were calculated wer the nitrite:ammonium consumption ratio and the nitrate:ammonium production ratio. Theoretically, these ratios should be 1.32:1 and 0.26:1 (Strous et al., 1998). These ratios were calculated from Day 55 (see Fig. 5) onwards and are depicted in Fig. 6. It can be seen that the experimentally obtained ratios are very close to the theoretical ratios. As such, it can be concluded that Anammox is present in the slow-fill reactor and that the start-up is successful.

\section{Conclusions}

In this paper the effect of feeding characteristics on the performance of the Anammox and partial nitritation reactor are discussed. For the partial nitritation reactor, the feeding regime is not important and start-up can be accomplished by slow or fast feeding. This is not the case for the Anammox reactor. Fast feeding leads to a high nitrite peak at the beginning of the feeding resulting in a slow start-up. Simulation results show that a slow filling period is needed to achieve good Anammox activity. The simulation results were confirmed by experimental laboratory-scale data.

\section{Acknowledgements}

The authors would like to thank the Institute for the Promotion of Innovation by Science and Technology in Flanders (IWT) for financial support (IWT Project No. 80126).

\section{References}

BLACKBURNE R, YUAN Z and KELLER J (2008) Demonstration of nitrogen removal via nitrite in a sequencing batch reactor treating domestic wastewater. Water Res. 42 2166-2176.

DAPENA-MORA A, VAN HULLE SWH, CAMPOS JL, MENDEZ R., VANROLLEGHEM PA and JETTEN M (2004) Enrichment of Anammox biomass from municipal activated sludge: experimental and results. J. Chem. Technol. Biotechnol. 79 1421-1428.

DE CLIPPELEIR H, VLAEMINCK SE, CARBALLA M and VERSTRAETE W (2009) A low volumetric exchange ratio allows high autotrophic nitrogen removal in a sequencing batch reactor. Bioresour. Technol. 100 5010-5015.

FUX C (2003) Biological Nitrogen Elimination of Ammonium-Rich Digester Liquids. PhD thesis, ETH-Zürich, Switzerland.

HAO XD, HEIJNEN JJ and VAN LOOSDRECHT MCM (2002) Sensitivity analysis of a biofilm model describing a one-stage completely autotrophic nitrogen removal (CANON) process. Biotechnol. Bioeng. 77 266-277.

HELLINGA C, SCHELLEN A, MULDER JW, VAN LOOSDRECHT MCM and HEIJNEN JJ (1998) The SHARON process: An innovative method for nitrogen removal from ammonium-rich waste water. Water Sci. Technol. 37 135-142.

HENZE M, VAN LOOSDRECHT M, EKAMA G and BRDJANOVIC D (2008) Biological Wastewater Treatment: Principles and Design. IWA Publishing, London. 511 pp.

HYUNGSEOK Y, KYU-HONG A, KWANG-HWAN L, YOUN-UNG K and KYUNG-GUEN S (1999) Nitrogen removal from synthetic wastewater by simultaneous nitrification and denitrification (SND) via nitrite in a intermittently-aerated reactor. Water Res. 33 145-154.

JANUS HM and VAN DER ROEST HF (1997) Don't reject the idea of treating reject water. Water Sci. Technol. 35 27-34.

JETTEN MSM, HORN SJ and VAN LOOSDRECHT MCM (1997) Towards a more sustainable municipal wastewater treatment system. Water Sci. Technol. 35 171-180.

JETTEN MSM, STROUS M, VAN DE PAS-SCHOONEN KT, SCHALK J, VAN DONGEN UGJM, VAN DE GRAAF AA, LOGEMANN S, MUYZER G, VAN LOOSDRECHT MCM and KUENEN JG (1999) The anaerobic oxidation of ammonium. FEMS Microbiol. Rev. 22 421-437.

KAMPSCHREUR MJ, TEMMINK H, KLEEREBEZEM R, JETTEN $M$ and VAN LOOSDRECHT MCM (2009) Nitrous oxide emission during wastewater treatment. Water Res. 43 4093-4103.

KATSOGIANNIS A, KORNAROS M and LYBERATOS G (2003) Enhanced nitrogen removal in SBRs by bypassing nitrate generation accomplished by multiple aerobic/anoxic phase pairs. Water Sci. Technol. 47 (11) 53-59.

TCHOBANANOGLOUS G, BURTON FL and STENSEL HD (2003) Wastewater Engineering: Treatment and Reuse ( $4^{\text {th }}$ edn.) Metcalf and Eddy Inc. and McGraw-Hill, New York, USA. 
STANDARD METHODS (1998) Standard Methods for the Examination of Water and Wastewater (20 ${ }^{\text {th }}$ edn.) American Public Health Association, Inc. (APHA) Washington, USA.

STROUS M, HEIJNEN JJ, KUENEN JG and JETTEN MSM (1998) The sequencing batch reactor as a powerful tool for the study of slowly growing anaerobic ammonium-oxidizing microorganisms. Appl. Microbiol. Biotechnol. 50 589-596.

VAN DE GRAAF AA, DE BRUIJN P, ROBERTSON LA, JETTEN MSM and KUENEN JG (1996) Autotrophic growth of anaerobic ammonium-oxidizing microorganisms in a fluidized bed reactor. Microbiol. 142 2187-2196.

VAN DER STAR WRL, ABMA WR, BLOMMERS D, MULDER JW, TOKUTOMI T, STROUS M, PICIOREANU C and VAN LOOSDRECHT MCM (2007) Startup of reactors for anoxic ammonium oxidation: Experiences from the first full-scale anammox reactor in Rotterdam. Water Res. 41 4149-4163.

VAN DONGEN U, JETTEN MSM and VAN LOOSDRECHT MCM (2001) The SHARON ${ }^{\circledR}$-Anammox ${ }^{\circledR}$ process for treatment of ammonium rich wastewater. Water Sci. Technol. 44 153-160.

VANHOOREN H, MEIRLAEN J, AMERLINCK Y, CLAEYS F, VANGHELUWE H and VANROLLEGHEM PA (2003) West: Modelling biological wastewater treatment. J. Hydroinformatics $527-50$.
VAN HULLE SWH, VAN DEN BROECK S, MAERTENS J, VILLEZ K, DONCKELS BMR, SCHELSTRAETE G, VOLCKE EIP and VANROLLEGHEM PA (2005) Construction, start-up and operation of a continuously aerated laboratory-scale SHARON reactor in view of coupling with an Anammox reactor. Water SA 31 327-334.

VAN HULLE SWH, VANDEWEYER HJP, MEESSCHAERT BD, VANROLLEGHEM PA, DEJANS P and DUMOULIN A (2010) Engineering aspects and practical application of autotrophic nitrogen removal from nitrogen rich streams. Chem. Eng. J. 162 1-20.

VEYS P, VANDEWEYER HJP, AUDENAERT W, MONBALLIU A DEJANS P, JOOKEN E, DUMOULIN A, MEESSCHAERT BD and VAN HULLE SWH (2010) Performance analysis and optimization of autotrophic nitrogen removal in different reactor configurations: A modeling study. Environ. Technol. 31 1311-1324.

WIESMANN U (1994) Biological nitrogen removal from wastewater. In: Fiechter A (ed.) Advances in Biochemical Engineering/ Biotechnology Vol. 51. Springer-Verlag, Berlin. 113-154.

WYFFELS S, VAN HULLE SWH, BOECKX P, VOLCKE EIP, VAN CLEEMPUT O, VANROLLEGHEM PA and VERSTRAETE W (2004) Modeling and simulation of oxygen-limited partial nitritation in a membrane-assisted bioreactor (MBR). Biotechnol. Bioeng. 86 531-542. 